$\begin{array}{r}\text { Contents lists available at BIOSFER } \\ \text { BIOSFER: JURNAL TADRIS BIOLOGI } \\ \begin{array}{c}\text { p-ISSN: 2086-5945 (print), e-ISSN: 2580-4960 (online), DoI 10.24042/biosfer } \\ \text { http://ejournal.radenintan.ac.id/index.php/biosfer/index }\end{array} \\ \hline \\ \hline\end{array}$

\title{
The Validity of Integrated Islamic Ethnobotany Textbook Based on the 3D Page Flip Application
}

\author{
Isnaini Siwi Handayani1 ${ }^{*}$; Ayatusa'adah²; Nanik Lestariningsih ${ }^{3}$ \\ 1, 2, 3 IAIN Palangka Raya, Indonesia
}

\begin{tabular}{l}
\hline ARTICLE INFO \\
\hline Article History \\
Received : 12-11-2020 \\
Accepted : 14-12-2020 \\
Published : 30-12-2020 \\
Keywords: \\
Validity; \\
Textbooks; \\
Ethnobotany; \\
Islamic Integrated; \\
3D Page Flip. \\
*Correspondence Address: \\
isnaini.siwi.handayani@gmail.com
\end{tabular}

\begin{abstract}
Based on the analysis of needs, it is known that Ethnobotany learning in the Biology Tadris study program at IAIN Palangka Raya has not used integrated Islamic teaching materials, lecturers and students need integrated Islamic Ethnobotany textbooks that are valid for use in learning. This study aims to describe the validity of the integrated Islamic Ethnobotany textbook based on the 3D PageFlip. This research is part of development research with the ADDIE development model. This study uses a quantitative descriptive method for feasibility assessment based on the expert review (including two material expert validators, two media expert validators, and two interpreter expert validators) using a questionnaire. The results of the study indicate that the assessment of the material expert is $94.5 \%$ (very valid), the assessment of the media expert is $90 \%$ (very valid), and the assessment of the interpreter is $90 \%$ (very valid). Thus, textbooks can be declared very valid and suitable for use in learning.

\section{Validitas Buku Ajar Etnobotani Terintegrasi Keislaman Berbas is Aplikasi 3D Page Flip}

\begin{abstract}
Abstrak: Berdasarkan analisis kebutuhan diketahui bahwa pembelajaran Etnobotani pada program studi Biologi Tadris di IAIN Palangka Raya belum menggunakan bahan ajar Islam terintegrasi, dosen dan mahasiswa membutuhkan buku ajar Etnobotani Islam terintegrasi yang valid untuk digunakan dalam pembelajaran. Penelitian ini bertujuan untuk mendeskripsikan validitas buku ajar Etnobotani terintegrasi keislaman berbasis aplikasi 3D PageFlip. Penelitian ini merupakan bagian dari penelitian pengembangan dengan model pengembangan ADDIE. Penelitian ini menggunakan metode deskriptif kuantitatif untuk penilaian kelayakan berdasarkan review ahli (meliputi dua validator ahli materi, dua validator ahli media, dan dua validator ahli tafsir) dengan menggunakan angket. Hasil penelitian menunjukkan bahwa penilaian ahli materi 94,5\% (sangat valid), penilaian ahli media 90\% (sangat valid), dan penilaian ahli tafsir 90\% (sangat valid). Dengan demikian, buku ajar dapat dinyatakan sangat valid dan layak digunakan dalam pembelajaran.
\end{abstract}


Biosfer, 11 (2) (2020) 129 - 138

Isnaini Siwi Handayani, Ayatusa'adah, Nanik Lestariningsih

\section{INTRODUCTION}

Technology in education must be used appropriately to improve the quality of students' learning experience (Aditia \& Muspiroh, 2013; Husain, 2014; Yuberti, 2015). Technological developments can be used in learning, especially in teaching materials (Cholik, 2017; Ferdianto \& Setiyani, 2018; Irwandani \& Juariyah, 2016; Putra, 2014). Technology can be used to develop electronic books (e-books). The electronic books can be presented more attractively by using the 3D Page Flip application (Alifya \& Rahman, 2020; Kurniawan et al., 2018; Simanjuntak et al., 2019). (Diani \& Hartati, 2018) state that 3D Page Flip is software that can be used to create e-books with 3D effects as teaching materials. This software is capable of converting Ms. Word files, PowerPoint files, and pdf into 3D flash e-books with various formats, such as Exe, Zip, Html, 3DP, Screen Saver, and others (ANGGRAENI, 2019). Thus, the flipbooks are more efficient and attractive using technology that supports current learning (Agustina \& Fitrihidajati, 2020; Priwantoro et al., 2018).

A textbook is an important factor so that learning at the tertiary level can run effectively and with quality (Ramdhani, 2017; Zaenuddin, 2018). Currently, science and society are developing rapidly. Students are expected to know various information; thus, the book should shorten the text and time (FAHMI YAFI \& Hakim, 2019; Fatmiyati, 2020; Rustaman, 2011). The educational book can be a writing tool in the education system following the curriculum (van den Ham \& Heinze, 2018). It is necessary to include the relationship between humans and plants in the Ethnobotany course (Cita \& Hasibuan, 2019; Leo et al., n.d.). Ethnobotany studies the use of plants in the daily life of indigenous peoples (Iswandono et al., 2015; Ristanto et al., 2020; Wijaya \& Oktarina, 2014). This study was also motivated by nature, local wisdom, and scientific repertoire improvement.

Considering the rapid development of technology, the developments in the world of education must be balanced between intellectual, emotional, and spiritual intelligence (Badiah, 2016; Masduki, 2016; Sulaiman et al., 2018). The spirituality presented in education will provide significant meaning for the life of a nation based on religious values (Arfandi, 2019; Hanif et al., 2016). Faith and religious knowledge are strong because scientific concepts are proven and implicit in religious teachings. Thus, the need for the integration of Islam in textbooks aims to build student character into individuals who are not only cognitively intelligent but also spiritually and emotionally intelligent (Mudlofir, 2016).

The education system of a nation has been polarized due to the entry of modern culture from the west which caused a gradual erosion of the Islamic identity of Muslim scholars. Therefore, efforts are needed to integrate science and Islamic values so that Muslim students are proud of their Muslim identity and apply Islamic laws in their daily lives (Asmara, 2016; Hanifah, 2018; Maryati \& Priatna, 2017; Mulyani, 2018).

Iswandono conducted research related to Ethnobotany in the relationship between humans and natural plants (Iswandono et al., 2015; Wijaya \& Oktarina, 2014). Larasati (Larasati et al., 2020; Suhandri \& Sari, 2019) integrated Islamic teachings into module development and Amirudin examined Islamic teachings with teaching materials (Amirudin \& Widiati, 2017; Ferdianto \& Setiyani, 2018; Kurniawan et al., 2018). However, research on teaching materials used a manual system which requires a lot of time, steps, and has not used an effective and simple but modern application, namely the 3D Page Flip. Based on this explanation, this 
Biosfer, 11 (2) (2020) 129 - 138

Isnaini Siwi Handayani, Ayatusa'adah, Nanik Lestariningsih

research was conducted by developing Islamic-based teaching materials with 3D Page Flip application to increase understanding and Islam. The purpose of this study was to determine the validity of the integrated Islamic Ethnobotany textbook based on the 3D Page Flip application based on expert assessment.

\section{METHOD}

This study was a quantitative descriptive study aimed to determine the validity of the integrated Islamic Ethnobotany textbook based on the 3D Page Flip application. The success rate of this study was based on the quantitative data on the validity of the textbook. This study did not provide any treatment to the subject.
Thus, data collection was carried out through a questionnaire while the data from observations, interviews, and students' initial needs analysis served as initial data. The subjects of this study were the validators.

Integrated Islamic Ethnobotany textbook based on the 3D Page Flip application must pass a validity test by the expert reviewers (two material experts, two media experts, and two interpreters) before it can be implemented in learning. The research instruments were observation sheets, interview list, student needs analysis sheets, and questionnaire sheets. This study was a research and development with the ADDIE procedure as the development model (Branch, 2009; Rodiawati \& Komarudin, 2018).

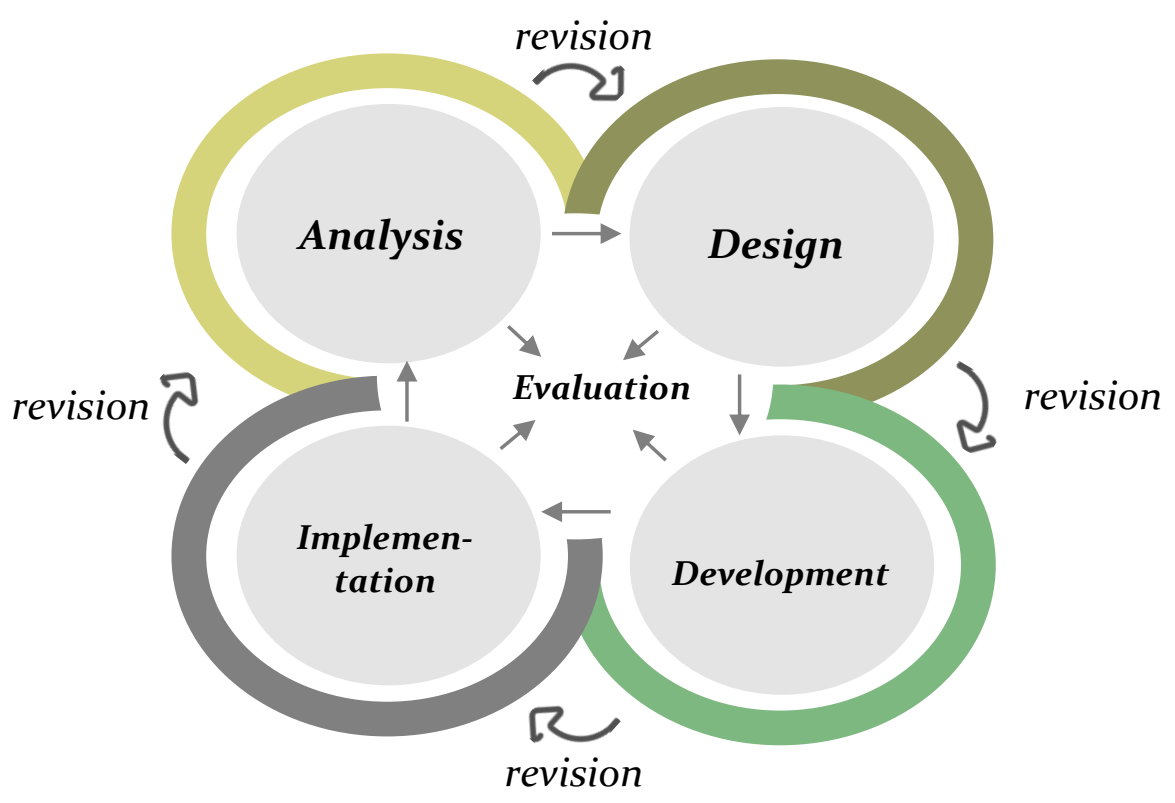

Figure 1. Steps from the ADDIE Development Model.

\section{RESULTS AND DISCUSSION}

The validity of the textbook was determined by three: material, media, and interpretation. The validation instrument was a Likert scale (4 scales). The material experts consisted of lecturers, one lecturer who teaches Ethnobotany subjects in the Biology Education Study Program at Lambung Mangkurat University, and one lecturer who teaches Ethnobiology in the Biology Education Study Program at 
Biosfer, 11 (2) (2020) 129 - 138

Isnaini Siwi Handayani, Ayatusa'adah, Nanik Lestariningsih

Palangka Raya University. The data obtained in Table 1. from material expert validation can be seen

Table 1. Material Expert Validation Results

\begin{tabular}{|c|c|c|c|c|c|}
\hline \multirow{2}{*}{ No. } & \multirow{2}{*}{ Aspect Assessment } & \multicolumn{2}{|c|}{ Phase 1} & \multicolumn{2}{|c|}{ Phase 2} \\
\hline & & Validator 1 & Validator 2 & Validator 1 & Validator 2 \\
\hline 1. & Content eligibility & 62 & 62 & 76 & 75 \\
\hline 2. & Presentation & 28 & 27 & 34 & 34 \\
\hline & Language & 48 & 46 & 54 & 53 \\
\hline \multicolumn{2}{|c|}{ Total score } & 138 & 135 & 164 & 162 \\
\hline \multicolumn{2}{|c|}{ Maximum score } & 172 & 172 & 172 & 172 \\
\hline \multicolumn{2}{|c|}{ Percentage } & $80 \%$ & $78 \%$ & $95 \%$ & $94 \%$ \\
\hline \multicolumn{2}{|c|}{ Average percentage } & \multicolumn{2}{|c|}{$79 \%$} & \multicolumn{2}{|c|}{$94,5 \%$} \\
\hline \multicolumn{2}{|c|}{ Criteria } & \multicolumn{2}{|c|}{ Valid } & \multicolumn{2}{|c|}{ Very Valid } \\
\hline \multicolumn{2}{|c|}{ Information } & \multicolumn{2}{|c|}{ Revise as necessary } & \multicolumn{2}{|c|}{ No need for revision } \\
\hline
\end{tabular}

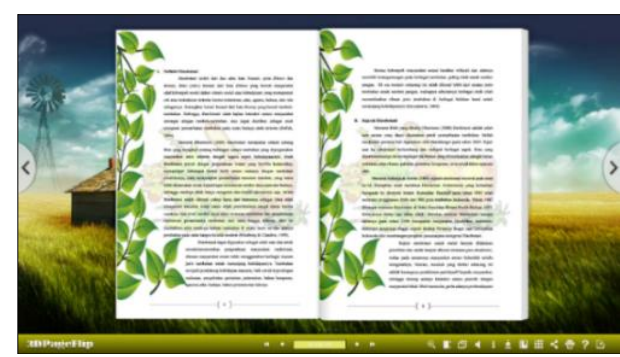

(a)

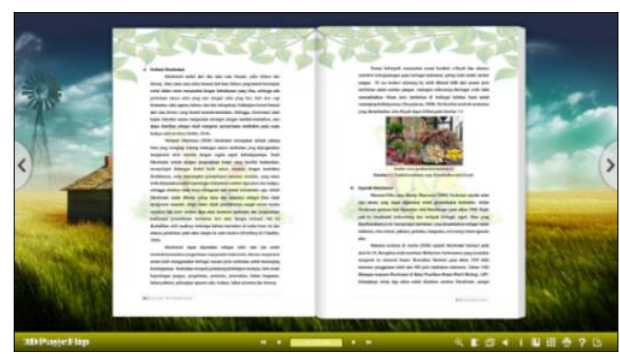

(b)

Figure 2. The Content of the Textbook Before (a) and after the Revision (b).

Media expert validation aimed to measure the graphic suitability of the product. The media contained in the product was assessed by two media experts, namely one lecturer who teaches Ethnobotany in the Biology Education Study Program at Lambung
Mangkurat University and one lecturer who teaches Biology Learning Media and Technology Courses in the Biology Education Study Program at IAIN Palangka Raya. The results of the media expert validation can be seen in Table 2 .

Table 2. The Results of Media Expert Validation

\begin{tabular}{|c|c|c|c|c|c|}
\hline \multirow{2}{*}{ No. } & \multirow{2}{*}{ Aspect Assessment } & \multicolumn{2}{|c|}{ Phase 1} & \multicolumn{2}{|c|}{ Phase 2} \\
\hline & & Validator 1 & Validator 2 & Validator 1 & Validator 2 \\
\hline 1. & Graphics & 79 & 72 & 98 & 85 \\
\hline 2. & Display & 49 & 45 & 55 & 51 \\
\hline 3. & Navigation & 16 & 13 & 20 & 16 \\
\hline \multicolumn{2}{|c|}{ Total score } & 144 & 130 & 173 & 152 \\
\hline \multicolumn{2}{|c|}{ Maximum score } & 180 & 180 & 180 & 180 \\
\hline \multicolumn{2}{|c|}{ Percentage } & $80 \%$ & $72 \%$ & $96 \%$ & $84 \%$ \\
\hline \multicolumn{2}{|c|}{ Average percentage } & \multicolumn{2}{|c|}{$76 \%$} & \multicolumn{2}{|c|}{$90 \%$} \\
\hline \multicolumn{2}{|c|}{ Criteria } & \multicolumn{2}{|c|}{ Valid } & \multicolumn{2}{|c|}{ Very Valid } \\
\hline \multicolumn{2}{|c|}{ Information } & \multicolumn{2}{|c|}{ Revise as necessary } & \multicolumn{2}{|c|}{ No need for revision } \\
\hline
\end{tabular}


Biosfer, 11 (2) (2020) 129 - 138

Isnaini Siwi Handayani, Ayatusa'adah, Nanik Lestariningsih

Based on the survey results, after revisions were made as recommended in stage 1 , the validity of the media textbooks in stage 2 received an average percentage of $90 \%$ (very valid). Thus, the textbook was declared feasible by media experts. The media assessment in terms of visual aspects followed the BSNP 2017 which consisted of display and navigation aspects. Visual aspects covered the book size, book cover, and content. The display aspects covered the overall pattern, arrangement, and verbal element. The navigation aspect covered

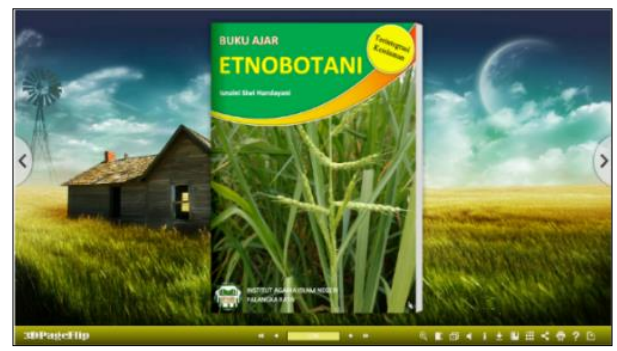

(a) navigation consistency, navigation effectiveness, navigation functions, ease of operation, and button consistency.

During the validation process, revisions were made based on the input from media experts in stage 1 validation. The product appearance changed based on the validator's recommendation. There were significant changes in the textbook so that it differs from the original product design. The changes were in the cover design and inner design of the book. The display changes can be seen in Figure 3.

Figure 3. Textbook Cover Before (a) and After Revision (b).

The interpreter validation checked the suitability of the relationship between the subject and verses of the Quran or Hadith. The interpretation was assessed by

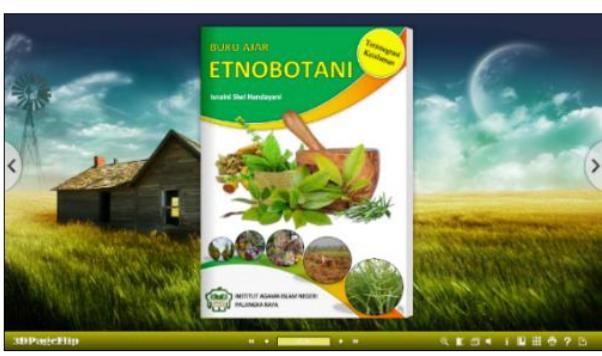

(b)

Table 3. The Results of Interpreter Validation

\begin{tabular}{|c|c|c|c|c|c|}
\hline \multirow{2}{*}{ No. } & \multirow{2}{*}{ Aspect Assessment } & \multicolumn{2}{|c|}{ Phase 1} & \multicolumn{2}{|c|}{ Phase 2} \\
\hline & & Validator 1 & Validator 2 & Validator 1 & Validator 2 \\
\hline 1. & $\begin{array}{l}\text { The suitability of the material with the } \\
\text { argument }\end{array}$ & 5 & 6 & 6 & 8 \\
\hline 2. & $\begin{array}{l}\text { The suitability between material } \\
\text { integration with theorem }\end{array}$ & 5 & 6 & 6 & 6 \\
\hline 3. & Reference compliance & 2 & 3 & 3 & 3 \\
\hline 4. & The accuracy of writing a verse or hadith & 6 & 7 & 7 & 8 \\
\hline 5. & $\begin{array}{l}\text { The accuracy of writing a verse or hadith } \\
\text { translation }\end{array}$ & 6 & 4 & 8 & 8 \\
\hline 6. & $\begin{array}{l}\text { The accuracy of writing the interpretation } \\
\text { of the verse }\end{array}$ & 5 & 5 & 6 & 7 \\
\hline 7. & Integration writing accuracy & 6 & 6 & 6 & 8 \\
\hline 8. & Paragraph letter consistency & 8 & 5 & 8 & 8 \\
\hline 9. & Material attractiveness & 7 & 7 & 8 & 8 \\
\hline 10. & The benefit of the material & 9 & 12 & 10 & 12 \\
\hline \multicolumn{2}{|c|}{ Total score } & 59 & 61 & 68 & 76 \\
\hline \multicolumn{2}{|c|}{ Maximum score } & 80 & 80 & 80 & 80 \\
\hline \multicolumn{2}{|c|}{ Percentage } & $73,7 \%$ & $76,2 \%$ & $85 \%$ & $95 \%$ \\
\hline \multicolumn{2}{|c|}{ Average percentage } & \multicolumn{2}{|c|}{$74,95 \%$} & \multicolumn{2}{|c|}{$90 \%$} \\
\hline \multicolumn{2}{|c|}{ Criteria } & \multicolumn{2}{|c|}{ Valid } & \multicolumn{2}{|c|}{ Very Valid } \\
\hline \multicolumn{2}{|c|}{ Information } & \multicolumn{2}{|c|}{ Revise as necessary } & \multicolumn{2}{|c|}{ No need for revision } \\
\hline
\end{tabular}


After the revisions were made according to recommendations in stage 1 , the validity of the textbook interpretation at stage 2 obtained an average percentage of 90\% (very valid). Thus, the textbook had been declared valid by the interpreters. The teaching materials are said to be valid in terms of integration if they have a harmonious relationship between the subject matter and the verses of the Quran (Alisyahbana, 2016; Hamdi, 2018). This study refers to the results of research conducted by Diani and Hartati (Diani \& Hartati, 2018) that the material experts validation obtained an average percentage of $95 \%$, media experts validation obtained an average percentage of $90 \%$, and the

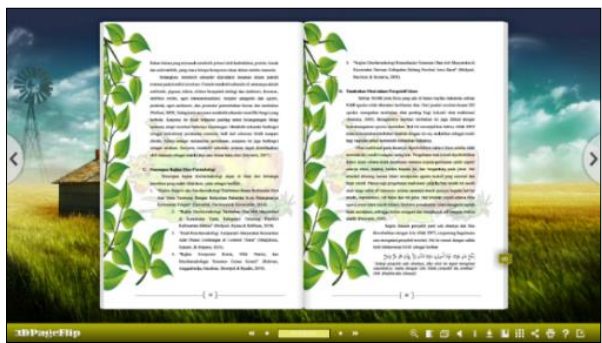

(a) religious experts' validation obtained an average percentage of $90 \%$. All the results of the questionnaire at the product validation stage obtained very feasible criteria.

During the validation process, revisions were made based on the input from the interpreters in validation phase 1. After the revision, the product appearance changed following the validator's recommendation. There were significant changes in the textbook so that it differs from the original product design. The changes can be found in the content of the material by adding verses and improving the content of the interpretation. The changes can be seen in Figure 4.

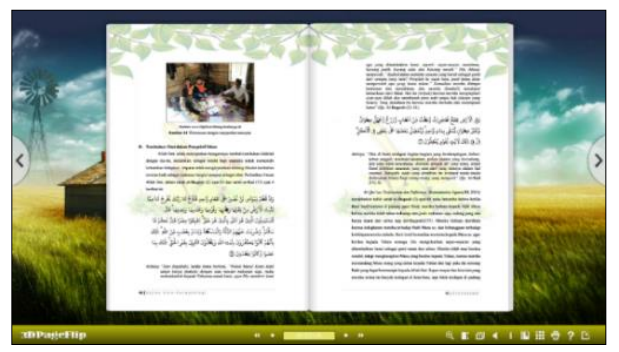

(b)

Figure 4. The Contents of the Textbooks Before (a) and After Revision (b).

The validity of this textbook was seen from 3 aspects, namely material, media, and interpretation. The validity of the textbook was measured based on the validation results. The validation was performed by the material, media, and interpretation experts who are experienced lecturers in their field. The validation process that was performed by two experts in each was intended to obtain more accurate textbook validity data. This is similar to previous research conducted by Wijayanti (Wijayanti, 2019) who conducted a validation stage by two experts in each field.

The results obtained are in line with previous research conducted by Marganda et.al (Marganda et al., 2020; Syahrowardi \& Permana, 2016) The results are that the 3D Page Flip application is effective in improving students' learning achievement and communication. (Mohammadi et al., 2019). Further research was conducted by Kuniawan et.al (Kurniawan et al., 2018; Shanthi \& Izzati, 2014) that Ethnobotany textbooks can hone and increase knowledge and insight. Next research was done by Larasati et.al (Larasati et al., 2020; Suhandri \& Sari, 2019) that Islam is good at increasing devotion, faith, and responsibility in learning.

In this study, the product validation was carried out twice by each validator in stage 1 and stage 2 . In stage 1 , the textbook had obtained valid criteria, but there were several corrections and recommendations from the validator. So, it is necessary to revise according to the recommendations. After completing the revision stage, the textbook was validated once more in stage 2. The value of the textbook validity increased and obtained very valid criteria. 
Thus, this textbook is valid and worthy to be tested on students. Referring to the results of research conducted by Wijayanti (Wijayanti, 2019), an integrated Islamic textbook based on the 3D Page Flip application is said to be valid if the validation results of material experts, media experts, and religious experts are high.

\section{CONCLUSIONS AND SUGGESTIONS}

Based on the results of the research and discussion, it can be concluded that the integrated Islamic Ethnobotany textbook based on the 3D Page Flip application is declared valid based on the experts' validation. The results obtained from the material experts were $94.5 \%$ (very valid), from the media experts were $90 \%$ (very valid), and from the interpreters were $90 \%$ (very valid). This textbook is suitable to be used in learning. However, the integrated Islamic Ethnobotany textbook based on the 3D Page Flip application still has many shortcomings and limitations in terms of material, limited discussion, and the file size. It opens up opportunities for research and reconstruction by updating and adding materials. It is suggested for further researchers to implement applications with a higher file capacity than $3 \mathrm{~d}$ Page Flip. This study can be used as a reference for further research and it is hoped that other researchers can develop the other fields.

\section{REFERENCES}

Aditia, M. T., \& Muspiroh, N. (2013). Pengembangan Modul Pembelajaran Berbasis Sains, Lingkungan, Teknologi, Masyarakat Dan Islam (Salingtemasis) Dalam Meningkatkan Hasil Belajar Siswa Pada Konsep Ekosistem Kelas X Di Sma NU (Nadhatul Ulama) Lemahabang Kabupaten Cirebon.
Scientiae Educatia: Jurnal
Pendidikan Sains, 2(2), 127-148.

Agustina, D. W., \& Fitrihidajati, H. (2020). Pengembangan Flipbook Berbasis Problem Based Learning $(\mathrm{Pbl})$ pada Submateri Pencemaran Lingkungan untuk Melatihkan Keterampilan Berpikir Kritis Peserta Didik Kelas X SMA. Berkala Ilmiah Pendidikan Biologi (BioEdu), 9(2), 325-339.

Alifya, N. F. H., \& Rahman, E. S. (2020). Efektivitas Penerapan Interaktif EBook Mata Pelajaran Pemrograman Dasar Pada Siswa SMK. Jurnal Media Elektrik, 17(2), 14-18.

Alisyahbana, T. (2016). Membangun Mentalitas Cinta Melalui Mata Kuliah Ilmu Budaya Dasar Dengan Nilai-nilai Islam Normatif. ELGhiroh, 10(1), 1-23.

Amirudin, A., \& Widiati, U. (2017). Pentingnya Pengembangan Bahan Ajar Tematik untuk Mencapai Pembelajaran Bermakna bagi Siswa Sekolah Dasar. Prosiding Seminar Nasional Mahasiswa Kerjasama Direktorat Jenderal Guru Dan Tenaga Kependidikan Kemendikbud 2016.

ANGGRAENI, R. (2019). Efektivitas Metode Pembelajaran Thinking Aloud Pair Problem Solving (Tapps) Berbantuan Media Audio-Visual Terhadap Kemampuan Berpikir Kritis Peserta Didik Kelas VIII Smp Taman Siswa Teluk Betung. UIN Raden Intan Lampung.

Arfandi, A. (2019). Spiritualitas Kepemimpinan dalam Pengelolaan Pendidikan dan Pembelajaran. Jurnal Pendidikan Islam Indonesia, 4(1), 50-65. 
Biosfer, 11 (2) (2020) 129 - 138

Isnaini Siwi Handayani, Ayatusa'adah, Nanik Lestariningsih

Asmara, A. P. (2016). Kajian Integrasi Nilainilai Karakter Islami dengan Kimia dalam Materi Kimia Karbon. JURNAL PENDIDIKAN SAINS (JPS), 4(2), 111.

Badiah, Z. (2016). Peranan Orang Tua dalam Mengembangkan Kecerdasan Emosional dan Spiritual (ESQ) Anak dalam Perspektif Islam. MUDARRISA: Jurnal Kajian Pendidikan Islam, 8(2), 229-254.

Branch, R. M. (2009). Instructional design: The ADDIE approach (Vol. 722). Springer Science \& Business Media.

Cholik, C. A. (2017). Pemanfaatan Teknologi Informasi Dan Komunikasi Untuk Meningkatkan Pendidikan Di Indonesia. Syntax Literate; Jurnal Ilmiah Indonesia, 2(6), 21-30.

Cita, K. D., \& Hasibuan, R. S. (2019). Utilization of Food Plant by Sundanese Ethnic, in Nyangkewok Hamlet, Sukabumi Regency. Media Konservasi, 24(3), 303-313.

Diani, R., \& Hartati, N. S. (2018). Flipbook berbasis literasi Islam: Pengembangan media pembelajaran fisika dengan 3D pageflip professional. Jurnal Inovasi Pendidikan IPA, 4(2), 234-244.

FAHMI YAFI, M., \& Hakim, L. (2019). Pengembangan Buku Teks Akuntansi Perbankan Syariah Berbasis Saintifik Pada Mata Pelajaran Akuntansi Perbankan Syariah Kelas XI Kompetensi Perbankan Syariah SMK Negeri 1 Lamongan. Jurnal Pendidikan Akuntansi (JPAK), 7(1).

Fatmiyati, F. (2020). Inovasi Pembelajaran Pendidikan Kreatif Menuju
Profesionalisme Guru. Prosiding Seminar Nasional Program Pascasarjana Universitas Pgri Palembang.

Ferdianto, F., \& Setiyani, S. (2018). Pengembangan Bahan Ajar Media Pembelajaran Berbasis Kearifan Lokal Mahasiswa Pendidikan Matematika. JNPM (Jurnal Nasional Pendidikan Matematika), 2(1), 3747.

Hamdi, S. (2018). Integrasi Budaya, Pendidikan, dan Politik dalam Dakwah Nahdlatul Wathan (NW) di Lombok: Kajian Biografi TGH. Zainuddin Abdul Madjid. Jurnal Sosiologi Walisongo, 2(2), 105-122.

Hanif, H., Ibrohim, I., \& Rohman, F. (2016). Pengembangan perangkat pembelajaran biologi materi plantae berbasis inkuiri terbimbing terintegrasi nilai islam untuk meningkatkan pemahaman konsep siswa sma. Jurnal Pendidikan: Teori, Penelitian, Dan Pengembangan, 1(11), 2163-2171.

Hanifah, U. (2018). Islamisasi Ilmu Pengetahuan Kontemporer (Konsep Integrasi Keilmuan di UniversitasUniversitas Islam Indonesia. TADRIS: Jurnal Pendidikan Islam, 13(2), 273-294.

Husain, C. (2014). Pemanfaatan teknologi informasi dan komunikasi dalam pembelajaran di SMA Muhammadiyah Tarakan. Jurnal Kebijakan Dan Pengembangan Pendidikan, 2(2).

Irwandani, I., \& Juariyah, S. (2016). Pengembangan media pembelajaran berupa komik fisika berbantuan sosial media instagram sebagai alternatif pembelajaran. Jurnal 
Biosfer, 11 (2) (2020) 129 - 138

Isnaini Siwi Handayani, Ayatusa'adah, Nanik Lestariningsih

Ilmiah Pendidikan Fisika Al-Biruni, 5(1), 33-42.

Iswandono, E., Zuhud, E. A. M., Hikmat, A., \& Kosmaryandi, N. (2015). Pengetahuan etnobotani Suku Manggarai dan implikasinya terhadap pemanfaatan tumbuhan hutan di Pegunungan Ruteng. Jurnal Ilmu Pertanian Indonesia, 20(3), 171-181.

Kurniawan, W., Pujaningsih, F. B., Alrizal, A., \& Latifah, N. A. (2018). Analisis Kebutuhan Mahasiswa terhadap Bahan Ajar sebagai Acuan untuk Pengembangan Modul Fisika Gelombang Bola dan Tabung. Edufisika: Jurnal Pendidikan Fisika, 3(01), 17-25.

Larasati, A. D., Lepiyanto, A., Sutanto, A., \& Asih, T. (2020). Pengembangan EModul Terintegrasi Nilai-Nilai Islam Pada Materi Sistem Respirasi. Didaktika Biologi: Jurnal Penelitian Pendidikan Biologi, 4(1), 1-9.

Leo, L., Syamswisna, S., \& Ariyati, E. (n.d.). Kelayakan Flipbook Materi Keanekaragaman Hayati Tumbuhan Obat Desa Seburing Kabupaten Sambas Kalimantan Barat. Jurnal Pendidikan Dan Pembelajaran Khatulistiwa, 7(11).

Marganda, A., Netriwati, N., \& Andriani, S. (2020). Media pembelajaran berbantuan 3D pageflip professional materi nilai mutlak. Prosiding Seminar Nasional Matematika Dan Pendidikan Matematika, 3(1), 2532.

Maryati, I., \& Priatna, N. (2017). Integrasi Nilai-Nilai Karakter Matematika melalui Pembelajaran Kontekstual. Mosharafa: Jurnal Pendidikan Matematika, 6(3), 333-344.
Masduki, Y. (2016). Pendidikan Kecerdasan Berbasis Keimanan. Jurnal Tarbiyatuna, 7(1), 53-81.

Mohammadi, J., Barati, H., \& Youhanaee, M. (2019). The Effectiveness of Using Flipped Classroom Model on Iranian EFL Learners' English Achievements and Their Willingness to Communicate. English Language Teaching, 12(5), 101-115. https://doi.org/10.5539/elt.v12n5p 101

Mudlofir, A. (2016). Pendidikan Karakter: Konsep dan Aktualisasinya dalam Sistem Pendidikan Islam. Nadwa, 7(2), 229-246.

Mulyani, A. (2018). Integrasi Ilmu Pengetahuan Alam dan Nilai-Nilai Islam Untuk Pembangunan Karakter Peserta Didik di Madrasah Aliyah. JEMST: Journal of Education in Mathematics, Science, and Technology, 1(1), 16-19.

Priwantoro, S. W., Fahmi, S., \& Astuti, D. (2018). Analisis Kebutuhan Pengembangan Multimedia Berbasis Kvisoft Dipadukan dengan Geogebra pada Matakuliah Program Linear. AdMathEdu, 8(1), 49-57.

Putra, I. E. (2014). Teknologi media pembelajaran sejarah melalui pemanfaatan multimedia animasi interaktif. Jurnal TeknoIf, 1(2).

Ramdhani, M. A. (2017). Lingkungan pendidikan dalam implementasi pendidikan karakter. Jurnal Pendidikan UNIGA, 8(1), 28-37.

Ristanto, R. H., Suryanda, A., Rismayati, A. I., Rimadana, A., \& Datau, R. (2020). Etnobotani: Tumbuhan ritual keagamaan hindu-bali. JPBIO (Jurnal Pendidikan Biologi), 5(1), 96-105. 
Biosfer, 11 (2) (2020) 129 - 138

Isnaini Siwi Handayani, Ayatusa'adah, Nanik Lestariningsih

Rodiawati, H., \& Komarudin, K. (2018). Pengembangan E-Learning Melalui Modul Interaktif Berbasis Learning Content Development System. Jurnal Tatsqif, 16(2), 172-185.

Rustaman, N. Y. (2011). Pendidikan dan Penelitian Sains dalam Mengembangkan Keterampilan Berpikir Tingkat Tinggi untuk Pembangunan Karakter. Proceeding Biology Education Conference: Biology, Science, Enviromental, and Learning, 8(1), 15-34.

Shanthi, R. V., \& Izzati, M. (2014). Studi etnobotani pengobatan tradisional untuk perawatan wanita di masyarakat Keraton Surakarta Hadiningrat. Biosaintifika: Journal of Biology \& Biology Education, 6(2), 61-69.

Simanjuntak, S. T., Supriyati, Y., \& Fahdiran, R. (2019). Pengembangan Buku Elektronik Pengayaan Pengetahuan Tentang Aplikasi Gelombang Ultrasonik Untuk Siswa SMA. Prosiding Seminar Nasional Fisika (E-Journal), 8, SNF2019-PE-17-24.

Suhandri, S., \& Sari, A. (2019). Pengembangan Modul Berbasis Kontekstual Terintegrasi Nilai Keislaman untuk Meningkatkan Kemampuan Pemecahan Masalah Matematis Siswa. Suska Journal of Mathematics Education, 5(2), 131140.

Sulaiman, M., Al Hamdani, M. D., \& Aziz, A. (2018). Emotional Spiritual Quotient (Esq) Dalam Pembelajaran Pendidikan Agama Islam Kurikulum 2013. Jurnal Penelitian Pendidikan Islam,[SL], 6(1), 77-110.
Syahrowardi, S., \& Permana, A. H. (2016). Desain handout multimedia menggunakan 3D pageflip professional untuk media pembelajaran pada sistem android. Jurnal Penelitian \& Pengembangan Pendidikan Fisika, 2(1), 89-96.

van den Ham, A.-K., \& Heinze, A. (2018). Does the textbook matter? Longitudinal effects of textbook choice on primary school students' achievement in mathematics. Studies in Educational Evaluation, 59, 133-140.

Wijaya, I., \& Oktarina, O. (2014). Sumbangan Ilmu Etnobotani dalam Memfasilitasi Hubungan Manusia dengan Tumbuhan dan Lingkungannya [Contributions In Science Ethnobotany Facilitate Human Relations With Plants And Environment]. Agritrop: Jurnal IlmuIlmu Pertanian Oournal of Agricultural Science), 12(1).

Wijayanti, M. (2019). Pengembangan Ebook IPA Fisika Berbasis Program Sigil Peserta Didik SMPN 23 Simbang Kabupaten Maros. Prosiding Seminar Nasional Fisika PPs Universitas Negeri Makassar, 1.

Yuberti, Y. (2015). Online Group Discussion pada Mata Kuliah Teknologi Pembelajaran Fisika. Jurnal Ilmiah Pendidikan Fisika Al-Biruni, 4(2), 145-153.

Zaenuddin, A. (2018). REVITALISASI PERPUSTAKAAN;(Upaya Menjadikan Perpustakaan Sebagai Sumber Pembelajaran Di Iain Sultan Amai Gorontalo). Madani: Jurnal Pengabdian Ilmiah, 1(1), 68-82. 